OPEN ACCESS

Edited by:

Rossana Berardi,

Marche Polytechnic University, Italy

Reviewed by:

Marco Schiavon,

University Hospital of Padua, Italy

Ilaria Alborelli,

University Hospital of Basel,

Switzerland

*Correspondence:

Bin Liang

bliang@hust.edu.cn

Chuansheng Zheng

hqzcsxh@sina.com

${ }^{\dagger}$ These authors have contributed equally to this work

Specialty section:

This article was submitted to

Thoracic Oncology,

a section of the journal

Frontiers in Oncology

Received: 17 February 2021 Accepted: 19 April 2021

Published: 11 May 2021

Citation:

Ouyang $T$, Cao $Y$, Kan $X$, Chen $L$,

Ren $Y$, Sun $T$, Yan L, Xiong B, Liang $B$ and Zheng $C$ (2021) Treatment-

Related Serious Adverse Events of Immune Checkpoint Inhibitors in Clinical Trials: A Systematic Review.

Front. Oncol. 11:621639.

doi: 10.3389/fonc.2021.621639

\section{Treatment-Related Serious Adverse Events of Immune Checkpoint Inhibitors in Clinical Trials: A Systematic Review}

Tao Ouyang ${ }^{1,2 \dagger}$, Yanyan Cao ${ }^{1,2 \dagger}$, Xuefeng Kan ${ }^{1,2 \dagger}$, Lei Chen ${ }^{1,2}$, Yanqiao Ren ${ }^{1,2}$, Tao Sun ${ }^{1,2}$, Liangliang Yan ${ }^{1,2}$, Bin Xiong ${ }^{1,2}$, Bin Liang ${ }^{1,2 *}$ and Chuansheng Zheng ${ }^{1,2 *}$

${ }^{1}$ Department of Radiology, Union Hospital, Tongji Medical College, Huazhong University of Science and Technology, Wuhan, China, ${ }^{2}$ Hubei Province Key Laboratory of Molecular Imaging, Wuhan, China

Background: Immune Checkpoint Inhibitors (ICI) have been progressively used in cancer treatment and produced unique toxicity profiles. This systematic review aims to comprehend the patterns and occurrence of treatment-related adverse events (trAEs) based on ICl.

Methods: PICOS/PRISMA methods were used to identify published English-language on PubMed, Web of Science, and Scopus from 2015 to 2020. Published clinical trials on $\mathrm{ICl}$ monotherapy, combined $\mathrm{ICls}$, and $\mathrm{ICl}$ plus other treatment with tabulated data on grade $\geq 3$ trAEs were included. Odds ratio (OR), $\chi^{2}$ tests were used to analyze for effect size and associations.

Results: This review included 145 clinical trials involving 21786 patients. Grade 3-5 trAEs were more common with $\mathrm{ICl}$ when they were plused with other treatments compared with ICl monotherapy(54.3\% versus $17.7 \%, 46.1 \%, p<0.05)$. Grade $3-5$ trAEs were also more common with CTLA-4 mAbs compared with anti-PD-1 and anti-PD-L1 (34.2\% versus $15.1 \%, 13.6 \%, p<0.05)$. Hyperthyroidism (OR 3.8, 95\% Cl 1.7-8.6), nausea (OR 3.7, 95\% $\mathrm{Cl}$ 2.5-5.3), diarrhea (OR 2.7, 95\% Cl 2.2-3.2), colitis (OR 3.4, 95\% Cl 2.7-4.3), ALT increase (OR 4.9, 95\% Cl 3.9-6.1), AST increase (OR 3.8, 95\%Cl 3.0-4.9), pruritus (OR 2.4, 95\% Cl 1.5-3.9), rash (OR 2.8, 95\% Cl 2.1-3.8), fatigue (OR 2.8, 95\% Cl 2.2-3.7), decreased appetite (OR 2.4, 95\% Cl 1.5-3.8), and hypophysitis (OR 2.0, 95\% Cl 1.2-3.3) were more frequent with combined ICls. Diarrhea (OR 8.1, 95\%Cl 6.4-10.3), colitis (OR 12.2, 95\% Cl 8.7-17.1), ALT increase (OR 5.1, 95\%Cl 3.5-7.4), AST increase (OR 4.2, $95 \% \mathrm{Cl}$ 2.8-6.3), pruritus (OR 4.1,95\% $\mathrm{Cl} 2.0-8.4$ ), rash (OR 4.4, 95\% Cl 2.9-6.8), hypophysitis (OR 12.1, 95\% Cl 6.3-23.4) were more common with CTLA-4 mAbs; whereas pneumonitis (OR 4.7, 95\% Cl 2.1-10.3) were more frequent with PD-1 mAbs.

Conclusions: Different immune checkpoint inhibitors are associated with different treatment-related adverse events profiles. A comprehensive data in this systematic review will provide comprehensive information for clinicians.

Keywords: immune checkpoint inhibitors, treatment-related adverse events, treatment-related death, immunerelated death, immune-related adverse events 


\section{INTRODUCTION}

Immune checkpoint inhibitors (ICI) are more and more being applied in many advanced solid cancers (1). ICI comprises cytotoxic T lymphocyte-associated protein-4 (CTLA-4), programmed cell death protein-1, and ligand-1 (PD-1 and PDL1) monoclonal antibodies. They interrupt the negative regulation of $\mathrm{T}$-cell responses and reactivate $\mathrm{T}$-cell mediated antitumor immunity by interacting with receptors on dendritic cells(CTLA-4 receptors), T cells(PD-1 receptors), antigenpresenting cells (anti-PD-L1), or tumor cells (anti-PD-L1) (2). To enhance treatment effect, combination therapies that involve CTLA-4 plus PD-1/PD-L1 antagonist, and ICI with chemotherapy or antiangiogenic agents. The combination of targeted molecules and other immune-based therapies was more effective than monotherapy in some advanced cancers (3). With increasingly frequent use of ICI across different patterns, understanding their treatment-related Adverse Events is crucial. Combination use of ICIs also results in a higher risk of treatment-related adverse events (trAEs) compared with ICI monotherapy, including thyroid dysfunction, colitis, pneumonitis, dermatitis, and hepatitis $(4,5)$.

To date, toxicity data for immune checkpoint inhibitors are mainly available from randomized controlled trials. Evidence on the relative risk of toxicities especially grade $\geq 3$ AEs between different classes of agents remains limited. Therefore, we conducted a systematic review of monotherapy and combination therapy of ICIs in randomized controlled trials which specifically examined for differences in grade $\geq 3$ trAEs, immune-related adverse events (irAEs), and toxic death.

\section{METHODS}

\section{Eligibility Criteria}

The following PICOS (Participants, Interventions, Control, Outcome and Study Design) criteria were used to define inclusion criteria for literature search:

1. Participants: The participants in the studies selected were patients with advanced cancer.

2. Interventions and control: The patients treated with different ICI monotherapy and combination.

3. Outcome: The occurrence of grade $\geq 3$ adverse events (AEs) in ICI monotherapy and combination.

4. Study design: The search criteria were conducted to identify published clinical trials of ICI monotherapy and combination which reported grade $\geq 3$ adverse events (AEs).

\section{Search Strategy and Study Selection}

We performed a systematic search to recognize published relevant clinical trials of monotherapy and combination therapy of ICIs that reported trAEs. PubMed, Web of Science, and Scopus were searched for relevant literature using keywords "nivolumab", "pembrolizumab", “atezolizumab”, "avelumab”, "durvalumab", “ipilimumab", "tremelimumab", “immune checkpoint inhibitors", "PD-1 inhibitor", "PD-L1 inhibitor", and "CTLA-4 inhibitor". The search was conducted from January 1, 2015 to March 1, 2020. Studies that met the following criteria were included: (1) clinical trials of advanced cancer treatment; (2) patients were treated with ICI monotherapy, CTLA-4 plus PD-1/PD-L1, or ICI plus other treatments; (3) reported tabulated data on immune-related or treatment-related grade $\geq 3$ adverse events; and (4) published in English. The literature search, research selection, and data extraction were acted separately by two reviewers (T.OY. and Y.Y.C), and any study that was thought to be potentially relevant was retrieved in full. Disagreements were resolved by consensus, but none occurred.

\section{Data Extraction}

The ICI agent, author name and year, phase, tumor type, number of patients, number of treatment-related 3-5 toxicities, number of deaths, death reason were collected from each selected study. trAEs, treatment-related deaths, irAEs and immune-related deaths were collected and analyzed. Adverse events that were not described as treatment-related or possibly unrelated to treatment were excluded. The data was extracted from the main text and Supplementary Information.

\section{Statistical Analysis}

Baseline characteristics were summarized using frequency and percentage. For most common trAEs, percentages were reported and used in all analyses. Odds ratio (OR) with 95\% confidence intervals (CI) were used to calculate the results of different ICI drugs and the use of ICI patterns (monotherapy, combined therapy and ICI plus chemotherapy). The $P$-values were calculated using the $\chi^{2}$ test and was listed in the tables. $P$-value $<0.05$ was considered statistically significant. All analyses were performed by SPSS 25.0.

\section{RESULTS}

\section{Study Selection and Characteristics}

The initial database originally identified 15035 relevant clinical trials. Finally, 145 studies involving 21786 patients meeting the inclusion criteria were included into this systematic review (Figure 1) (6-146). Additional Table S1 summarizes the trial and patient characteristics. The trials involved the treatment as monotherapy $(n=104)$, combined therapy of two ICIs $(n=20)$, and ICI in combination with chemotherapy or other treatments $(n=33)$. The ICI monotherapy arms that were used in our study included PD-1 inhibitors ( $\mathrm{n}=75)$, PD-L1 inhibitors $(\mathrm{n}=18)$, and CTLA-4 inhibitors $(n=17)$. The combined ICIs treatment arm that was used in our study included PD-1 inhibitors combining with CTLA-4 inhibitors $(\mathrm{n}=18)$, and PD-L1 inhibitors plus CTLA-4 inhibitors $(n=2)$. Moreover, the included clinical trials involved the cancer type of melanoma $(n=37)$, lung cancer $(n=36)$, renal cell cancer $(n=10)$, urothelial cancer $(n=9)$, gastrointestinal cancer $(n=7)$, head and neck squamous cell cancer $(n=7)$, breast cancer $(n=7)$, and other cancers $(n=32)$. 

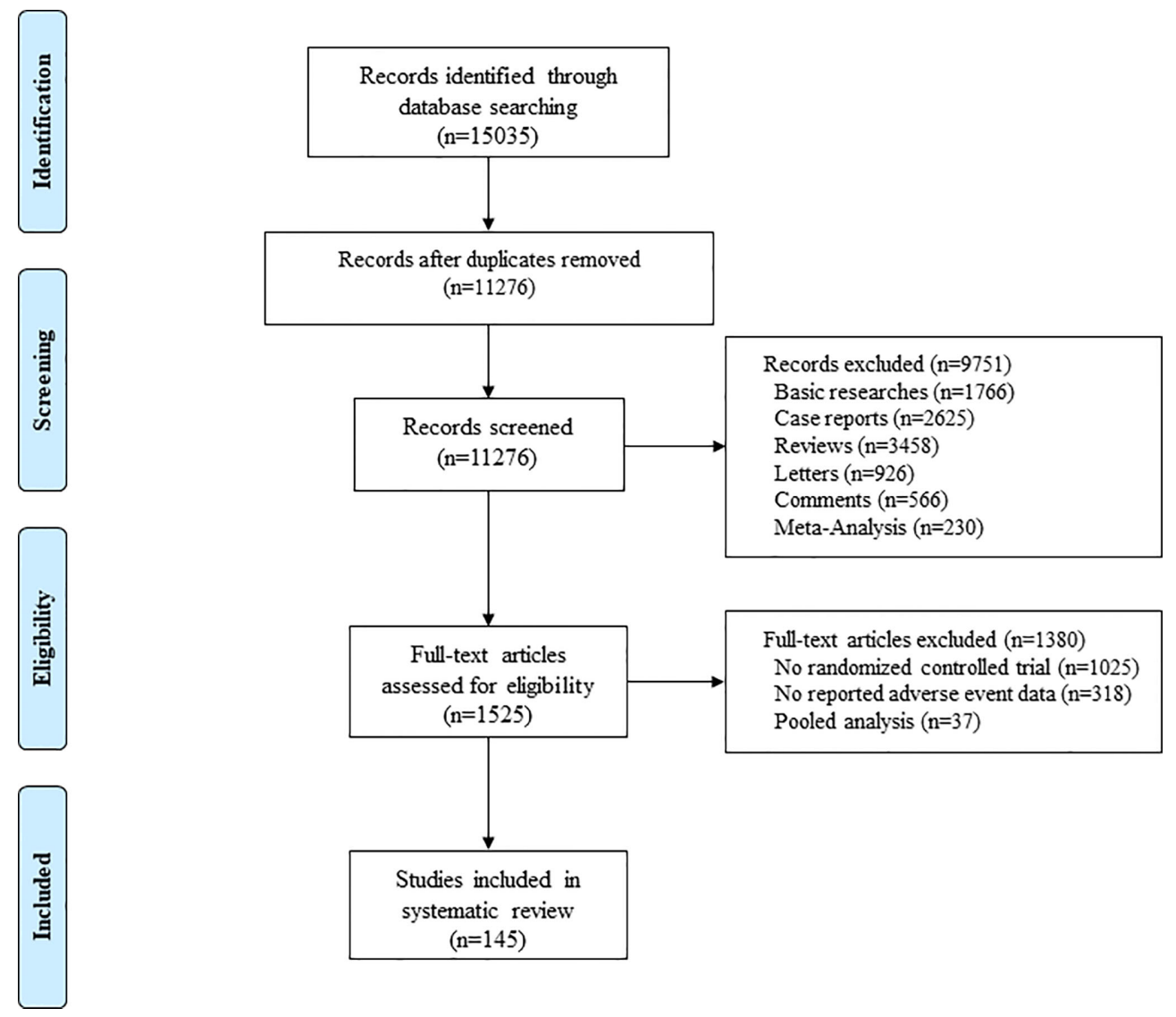

FIGURE 1 | Flow Diagram of the Study Selection Process.

Almost all trials had tumor metastatic, except for 17 trials. This systematic review included 48 phase I, 8 phase I/II, 59 phase II and 30 phase III clinical trials.

For the systematic review, we analyzed adverse events that reported by more than $5 \%$ of the clinical trials. We defined ICI monotherapy, combined therapy of two ICIs, and ICI plus other treatments as cohort 1 , cohort 2 and cohort 3, respectively.

\section{Overall Incidence of Grade $\geq 3$ trAEs}

Collectively, all of the included clinical trials reported over 100 kinds of adverse events. On the whole, at least 1 grade 3 or higher adverse event occurred in 5,599 (25.7\%) of 21,786 patients in 145 studies. In the ICI monotherapy treatment group, at least 1 grade 3 or higher adverse event occurred in 2889 (17.7\%) of 16395 patients in 104 studies. Moreover, in the combined ICIs treatment group, $1531(46.1 \%)$ of 3321 patients from 20 studies developed grade $\geq 3$ AEs, and 1179 (54.3\%) of 2170 in ICI plus other treatments group. The most commonly reported trAEs were hypothyroidism, nausea, hyperthyroidism, diarrhea, colitis, alanine aminotransferase (ALT) increase, Aspartate aminotransferase (AST) increase, rash, arthralgia, myalgia, pruritus, pneumonitis, fatigue, decreased appetite, and hypophysitis. The incidence of treatment-related grade 3-5 AEs, treatment-related death, immune-related grade 3-5 AEs, and immune-related death are shown in Table 1. Additional Table S2 reports the percentages of these common adverse events in three cohorts and different ICI agents.

\section{Incidence of Grade $\geq 3$ trAEs According to Study Groups}

Grade $\geq 3$ trAEs were more frequent in the group of ICI plus other treatments (cohort 3) compared with the groups of ICI monotherapy (cohort1) and combined therapy of two ICIs (cohort2) (54.3, 95\% CI 52.2-56.4; 17.7, 95\% CI 17.1-18.3; 46.1, 95\% CI 44.4-47.8, respectively). However, Grade $\geq 3$ irAEs were more common in cohort 2 compared with that of in cohort 1 and cohort 3 (24.5, 95\% CI 23.0-26.0; 5.9, 95\% CI 5.6-6.3; 10.6, 95\% CI 9.3-11.9), these results are provided in Table 2. Grade $\geq 3$ hyperthyroidism (OR 3.8, 95\% CI 1.7-8.6), nausea (OR 3.7, 95\% CI 2.5-5.3), diarrhea (OR 2.7, 95\% CI 2.2-3.2), colitis (OR 3.7, 95\% CI 2.7-4.3), ALT increase (OR 4.9, 95\% CI 3.9-6.1), AST increase (OR 3.8, 95\% CI 3.0-4.9), pruritus (OR 2.4, 95\% CI 1.53.9), rash (OR 2.8, 95\% CI 2.1-3.8), fatigue (OR 2.8, 95\% CI 2.23.7 ), decreased appetite (OR 2.4, 95\% CI 1.5-3.8), and 
TABLE 1 | Overall incidence of grade $\geq 3$ trAEs and irAEs.

\begin{tabular}{|c|c|c|c|c|c|}
\hline Cohort/agent & No. of patients & Treatment-related 3-5 AEs & Treatment-related death & Immune-related 3-5 AEs & Immune-related death \\
\hline 1 & 16295 & $2889(17.7 \%)$ & $71(0.4 \%)$ & 969 (5.9\%) & $34(0.2 \%)$ \\
\hline 2 & 3321 & $1531(46.1 \%)$ & $39(1.2 \%)$ & $814(24.5 \%)$ & $16(0.5 \%)$ \\
\hline 3 & 2170 & $1179(54.3 \%)$ & $58(2.7 \%)$ & $230(10.6 \%)$ & $5(0.2 \%)$ \\
\hline PD-1 inhibitors & 10407 & $1567(15.1 \%)$ & $46(0.4 \%)$ & 336 (3.2\%) & $17(0.2 \%)$ \\
\hline PD-L1 inhibitors & 3350 & $455(13.6 \%)$ & $14(0.4 \%)$ & $81(2.4 \%)$ & $8(0.2 \%)$ \\
\hline CTLA-4 inhibitors & 2538 & $867(34.2 \%)$ & $11(0.4 \%)$ & $552(21.7 \%)$ & $1(0.04 \%)$ \\
\hline
\end{tabular}

Cohort 1: ICl monotherapy; Cohort 2: combined therapy of two ICls; Cohort 3: ICl plus other treatments.

The incidence of AEs in different types of ICI included only monotherapy trials.

TABLE 2 | Comparison of grade $\geq 3$ trAEs and irAEs from 3 cohorts.

\begin{tabular}{|c|c|c|c|c|c|c|}
\hline & Cohort 1 Vs Cohort 2 & $P$ value & Cohort 1 Vs Cohort 3 & $P$ value & Cohort 2 Vs Cohort 3 & $P$ value \\
\hline \multirow[t]{3}{*}{ Treatment-related 3-5 AEs } & 17.7 (17.1-18.3) & $P<0.001$ & 17.7 (17.1-18.3) & $P<0.001$ & $46.1(44.4-47.8)$ & $P<0.001$ \\
\hline & Vs & & Vs & & Vs & \\
\hline & $46.1(44.4-47.8)$ & & $54.3(52.2-56.4)$ & & $54.3(52.2-56.4)$ & \\
\hline \multirow[t]{3}{*}{ Treatment-related death } & $0.4(0.3-0.5)$ & $P<0.001$ & $0.4(0.3-0.5)$ & $P<0.001$ & $1.2(0.8-1.5)$ & $P<0.001$ \\
\hline & Vs & & $V_{s}$ & & Vs & \\
\hline & $1.2(0.8-1.5)$ & & $2.7(2.0-3.4)$ & & $2.7(2.0-3.4)$ & \\
\hline \multirow[t]{3}{*}{ Immune-related 3-5 AEs } & $5.9(5.6-6.3)$ & $P<0.001$ & $5.9(5.6-6.3)$ & $P<0.001$ & $24.5(23.0-26.0)$ & $P<0.001$ \\
\hline & Vs & & Vs & & Vs & \\
\hline & 24.5 (23.0-26.0) & & $10.6(9.3-11.9)$ & & $10.6(9.3-11.9)$ & \\
\hline \multirow[t]{3}{*}{ Immune-related death } & $0.2(0.1-0.3)$ & $P=0.004$ & $0.2(0.1-0.3)$ & $P=0.836$ & $0.5(0.2-0.7)$ & $P=0.14$ \\
\hline & Vs & & Vs & & Vs & \\
\hline & $0.5(0.2-0.7)$ & & $0.2(0-0.4)$ & & $0.2(0-0.4)$ & \\
\hline
\end{tabular}

Cohort 1: ICI monotherapy; Cohort 2: combined therapy of two ICIs; Cohort 3: ICI plus other treatments.

hypophysitis (OR 2.0, 95\% CI 1.2-3.3) were more frequent with cohort 2 compared with cohort 1 (Table 3).

\section{Incidence of Grade $\geq 3$ trAEs According to ICI Class}

Grade $\geq 3$ trAEs were more likely to happen in CTLA-4 compared with PD-1 ICI and PD-L1 ICI (34.2, 95\% CI 32.336.0; 15.1, 95\% CI 14.4-15.7; 13.6, 95\% CI 12.4-14.7). Similar results were obtained in Grade $\geq 3$ irAEs. In comparison of irAEs from the monotherapy showed that CTLA-4 had a significantly higher frequency of Grade $\geq 3$ irAEs compared with PD-1 and PD-L1 (21.7, 95\% CI 20.1-23.4,; 3.2, 95\% CI 2.9-3.6, $p<0.001 ; 2.4$, 95\% CI 1.9-2.9, $p<0.001$ ) (Table 4). The differences of AEs in different types of ICI included only monotherapy trials. Diarrhea (OR 8.1, 95\% CI 6.4-10.3),

TABLE 3 | Comparison of grade $\geq 3$ trAEs between cohort 1 and 2 .

\begin{tabular}{lll}
\hline & OR (95\% Cl) & $P$ value \\
\hline Hyperthyroidism & $3.8(1.7-8.6)$ & $P=0.001$ \\
Nausea & $3.7(2.5-5.3)$ & $P<0.001$ \\
Diarrhea & $2.7(2.2-3.2)$ & $P<0.001$ \\
Colitis & $3.4(2.7-4.3)$ & $P<0.001$ \\
ALT increase & $4.9(3.9-6.1)$ & $P<0.001$ \\
AST increase & $3.8(3.0-4.9)$ & $P<0.001$ \\
Pruritus & $2.4(1.5-3.9)$ & $P<0.001$ \\
Rash & $2.8(2.1-3.8)$ & $P<0.001$ \\
Fatigue & $2.8(2.2-3.7)$ & $P<0.001$ \\
Decreased appetite & $2.4(1.5-3.8)$ & $P<0.001$ \\
Hypophysitis & $2.0(1.2-3.3)$ & $P=0.007$ \\
\hline
\end{tabular}

Cohort 1: ICl monotherapy; Cohort 2: combined therapy of two ICls. colitis (OR 12.2, 95\% CI 8.7-17.1), ALT increase (OR 5.1, 95\% CI 3.5-7.4), AST increase (OR 4.2, 95\% CI 2.8-6.3), pruritus (OR 4.1, 95\% CI 2.0-8.4), rash (OR 4.4, 95\% CI 2.9-6.8), hypophysitis (OR 12.1, 95\% CI 6.3-23.4) were more frequent when patients received the treatment of CTLA-4 ICI; whereas pneumonitis (OR 4.7, 95\% CI 2.1-10.3) were more common when patients received the treatment of PD-1 monoclonal antibodies (Table 5).

\section{Incidence of Treatment-Related Death and Immune-Related Death}

Among the studies, 59 clinical trials reported treatment-related death, and a total of 165 such deaths reported (Additional Table S1). The occurrence of treatment-related death in all studies was $0.75 \%$ (165 of 21786). The incidence of treatmentrelated death was more common with ICI plus chemotherapy (cohort 3) compared with ICI monotherapy (cohort 1) $(2.7,95 \%$ CI 2.0-3.4 versus $0.4,95 \%$ CI 0.3-0.5). Immune-related death were more frequent in cohort 2 compared with cohort $1(0.5$, 95\% CI $0.2-0.7$ versus $0.2,95 \%$ CI $0.1-0.3$ ). According to the ICI class, the comparison of treatment-related death and immunerelated death were not statistically significant. All the results were provided in Tables 2 and 4 .

\section{DISCUSSION}

We performed a systematic review of monotherapy, combination therapy of ICIs, and ICI inhibitor with other treatment relevant 
TABLE 4 | Comparison of grade $\geq 3$ trAEs and irAEs from 3 ICls.

\begin{tabular}{|c|c|c|c|c|c|c|}
\hline & PD-1 Vs PD-L1 & $P$ value & PD-1 Vs CTLA-4 & $P$ value & PD-L1 Vs CTLA-4 & $P$ value \\
\hline \multirow[t]{3}{*}{ Treatment-related 3-5 AEs } & $15.1(14.4-15.7)$ & $P=0.036$ & $15.1(14.4-15.7)$ & $P<0.001$ & $13.6(12.4-14.7)$ & $P<0.001$ \\
\hline & $V_{s}$ & & Vs & & Vs & \\
\hline & $13.6(12.4-14.7)$ & & $34.2(32.3-36.0)$ & & $34.2(32.3-36.0)$ & \\
\hline \multirow[t]{3}{*}{ Treatment-related death } & $0.4(0.3-0.6)$ & $P=0.854$ & $0.4(0.3-0.6)$ & $P=0.953$ & $0.4(0.2-0.6)$ & $P=0.928$ \\
\hline & Vs & & Vs & & Vs & \\
\hline & $0.4(0.2-0.6)$ & & $0.4(0.2-0.7)$ & & $0.4(0.2-0.7)$ & \\
\hline \multirow[t]{3}{*}{ Immune-related 3-5 AEs } & $3.2(2.9-3.6)$ & $P=0.017$ & $3.2(2.9-3.6)$ & $P<0.001$ & $2.4(1.9-2.9)$ & $P<0.001$ \\
\hline & Vs & & Vs & & Vs & \\
\hline & $2.4(1.9-2.9)$ & & $21.7(20.1-23.4)$ & & $21.7(20.1-23.4)$ & \\
\hline \multirow[t]{3}{*}{ Immune-related death } & $0.2(0.1-0.2)$ & $P=0.372$ & $0.2(0.1-0.2)$ & $P=0.133$ & $0.2(0.1-0.4)$ & $P=0.052$ \\
\hline & Vs & & Vs & & Vs & \\
\hline & $0.2(0.1-0.4)$ & & $0(0-0.1)$ & & $0(0-0.1)$ & \\
\hline
\end{tabular}

The incidence of AEs in different types of ICI included only monotherapy trials.

TABLE 5 | Comparison of grade $\geq 3$ trAEs between CTLA-4 and PD1/PD-L1.

\begin{tabular}{|c|c|c|c|c|}
\hline & PD1/PD-L1 OR (95\% Cl) & $P$ value & CTLA-4 OR (95\% Cl) & $P$ value \\
\hline Diarrhea & & & $8.1(6.4-10.3)$ & $P<0.001$ \\
\hline Colitis & & & $12.2(8.7-17.1)$ & $P<0.001$ \\
\hline ALT increase & & & $5.1(3.5-7.4)$ & $P<0.001$ \\
\hline AST increase & & & $4.2(2.8-6.3)$ & $P<0.001$ \\
\hline Pruritus & & & $4.1(2.0-8.4)$ & $P<0.001$ \\
\hline Rash & & & $4.4(2.9-6.8)$ & $P<0.001$ \\
\hline Pneumonitis & $4.7(2.1-10.3)$ & $P<0.001$ & & \\
\hline Hypophysitis & & & $12.1(6.3-23.4)$ & $P<0.001$ \\
\hline
\end{tabular}

adverse events based on data from published clinical trials. Meanwhile, we executed a subgroup analysis to compare the difference of PD-1, PD-L1 and CTLA-4 inhibitors in the treatment-related and immune-related adverse events. This systematic review analyzed the number of each adverse event associated with different ICIs to draw precise statistical inferences that were close or even the same as the results of individual-level data, which was different from the meta-analyses that used continuous summary statistics based on the largesample theory. To date, this systematic review was the first and most comprehensive study of treatment-related serious adverse events for three treatment modalities involving ICIs. A comprehensive analysis of the unique adverse events associated with different ICIs reported in clinical trials will aid clinicians in providing comprehensive information.

The precise mechanism of trAEs is still unknown, it may relate to block inhibitory checkpoints and activate T-cell immune. Recently, several hypotheses are suggested. First, the use of immune checkpoint inhibitors disrupts the immunologic homeostasis and reduces T-cell tolerance (147). Second, there is some cross-reaction of T-cells between tumor cells and normal tissue (148). Third, immune checkpoint inhibitors can increase scales of preexisting autoantibodies and inflammatory cytokines (149). For these facts, activated T-cells assault normal tissue resulting in trAEs. Although many clinical practice guidelines of trAEs have been published recently, such as the American Society of Clinical Oncology and National Comprehensive Cancer Network guidelines (150), trAEs present an entirely new set of clinical challenges. These autoimmune toxicities are incredibly diverse, potentially affecting almost every organ system (151). In our study, the most common reported trAEs were diarrhea, colitis, ALT increase, AST increase, and fatigue. Less common but potentially more serious trAEs include pneumonitis and hypophysitis. Less common still are dreaded effects on the heart and central nervous system, which were not mentioned in our article.

Our study has demonstrated that the incidence of serious trAEs associated with PD-1/PD-L1 agents was significantly lower than that of the CTLA-4 inhibitors $(15.1 \%, 13.6 \%$ and $34.2 \%$, respectively). In general, anti-CTLA-4 agents was more toxic than anti-PD-1/PD-L1 agent, which is consistent with our results (152). However, there was no significant difference in the treatment-related death among PD-1, PD-L1, and CTLA-4 inhibitors $(0.4 \%, 0.4 \%$ and $0.4 \%$, respectively). This finding may be explained that the majority of serious AEs (grade $\geq 3$ ) were reversible after the systemic apply of glucocorticoids, then, manage properly. CTLA-4 and PD-1 are separate pathways from both a spatial and a chronological standpoint (153). CTLA-4 can prevent the interaction between class II major histocompatibility complex molecules of the antigen presenting cells, and the T-cell receptor to inhibit the activation of T cells (154). More recently, CTLA-4 has also been implicated in the function of Tregs, which suppress effector T-cell activation and function $(155,156)$. However, the precise mechanism and role for CTLA-4 Treg function is a much-debated topic. Anti-CTLA-4 antibodies can lead to an interruption of peripheral tolerance by activated T-cell and Treg cells (157). To date, the precise mechanism of PD-1 in $\mathrm{T}$-cell tolerance is not completely clear. It plays its function 
mostly in peripheral tissues, inducing a homeostatic inhibition of previously activated T-cells (158). Besides, PD-1 may inhibit Tcell function and survival directly, by blocking early activation signals that are promoted by CD28, or indirectly through IL2 (159).

This review indicated that the majority of reported serious adverse events were related to immune-related, including pneumonitis, diarrhea, colitis, elevated ALT and AST, hyperthyroidism, and hypophysitis. High-dose corticosteroids were the first line for treating irAEs and may help to enable their proper management. If not detected and cured early, these immune-related toxicities will make progression and may even endanger life. This systematic review showed that the immunerelated serious adverse events was significantly higher in CTLA-4 inhibitors than that of in PD-1 and PD-L1 inhibitors $21.7 \%$, $3.2 \%, 2.4 \%$ respectively). According to the previous studies, the incidence of grade 3 or higher irAEs ranges from 15\% to $42 \%$ in anti-CTLA- 4 agents, $5 \%$ to $10 \%$ in anti-PD-1 agents, and $1 \%$ to $7 \%$ in anti-PD-L1 agents (150). Our results are in agreement with these previous research. Nonetheless, there was no statistical difference in immune-related deaths among the three monotherapies.

According to the previous study reported, one of the most common adverse events caused by ICI was endocrinological diseases (160). Although all the endocrine glands may be invaded, in our study, the thyroid and hypophysis were the most constantly invaded organs. Although not fully understood, the mechanism of immune-related thyroid dysfunction comprises autoimmune thyroiditis, mediated by T-cell cytotoxicity, natural killer cells, and PD-1/PD-L1 expression in thyroid tissue (161). Hypophysitis is more likely to occur in patients with anti-CTLA-4 agents as an on-target effect of ectopic CTLA-4 protein expression in the pituitary gland, antibody-dependent cell-mediated cytotoxicity (ADCC), and activation of the complement pathway (162). This conclusion is consistent with our research that the prevalence of hypophysitis in patients receiving anti-CTLA-4 agents was higher than that of patients receiving anti-PD-1/PD-L1 agents (odds ratio [OR] 12.1, 95\% confidence interval [CI] 6.3-23.4). Skin toxicity (rash and pruritus), digestive tract disorders (Diarrhea, Colitis, ALT increase and AST increase), and rheumatologic disorders(Arthralgia/Myalgia) are the most frequent adverse events occurred in patients with anti-CTLA4 agents, except for pneumonitis which is common reported in anti-PD-1/anti-PD-L1 agents(4.7, 95\% CI 2.1-10.3). Although the precise underlying mechanism remains unclear, there was a hypothesis indicated that alveolar macrophages probably hyperactivated in patients who received anti-PD-1 agents. This hypothesis is sustained by the phenomenon that interstitial macrophages and alveolar cells express repulsive guidance molecule B (RGMB) in the surface, which may act as a ligand to PD-L2 (163).

Indeed, ICI monotherapy benefits just a few patients, with objective response rates (ORR) of about 15-25\%, and even lower for pancreatic carcinoma, prostate cancer, ovarian carcinoma, triple-negative breast cancer, and microsatellite stable colorectal cancer. It may be attributed to tumor heterogeneity and tumor resistance (164). Therefore, many researches were focused on seeking the combination strategies which can improve antitumor immunity and increase treatment efficacy. To date, the majority of combination strategy was immune checkpoint inhibitors with antiangiogenic agents, ICI with chemotherapy, and combined of two ICIs. Some previous literatures had demonstrated that a higher incidence of adverse events was recorded in employing ICI combination compared with ICI monotherapy $(3,4)$. Interestingly, our research indicated that ICI plus chemotherapy or antiangiogenic agent(cohort 3) had the highest adverse events and treatment-related death. The higher frequency of severe AEs in cohort 3 probably illustrated by the multiple targets of TKIs. The toxicities include not only adverse events that were related to the barricade of the VEGR/ VEGFR pathway, but also adverse events that were caused by extra targets inhibition (165). Generally, the combination therapy strategy had a high occurrence of trAEs, including any grade trAEs, and grade 3 or higher trAEs. In contrast, ICI combination can increase the benefit derived from ICI monotherapy in tumors which already responsive to ICI monotherapy. However, due to the lack of enough clinical results comparing the ICI combination to ICI monotherapy, it is currently difficult to conduct accurate risk-benefit analysis of ICI combination.

Pneumonitis and cardiac causes were the most common treatment-related deaths in our study. According to reports, the incidence of ICI-related pneumonitis that was reported in clinical trials in ICI monotherapy is $2.5 \%-5.0 \%$, and in combination therapy ranges from $7 \%$ to $10 \%$ (166). Moreover, compared with CTLA-4 inhibitors, PD-1/PD-L1 agents performed a higher incidence and severity of pulmonary adverse events (167). This finding is consistent with our results. The treatment of pneumonitis is ICI cessation, systemic steroids, and immunosuppressive medications. If ICIs are reused, ICI-related pneumonitis can recrudesce in $20 \%$ of patients (168). The most common ICIrelated cardiotoxicity is myocarditis. ICI-related cardiotoxicity is relatively limited but life-threatening and deadly. Therefore, clinicians should more focus on cardiotoxicity, especially of grade 3 or higher in immunotherapy (169).

There are limitations in our study. The heterogeneity among included studies cannot be ignored. In addition, cancer types, phase of trial, number of patients and criteria for reporting adverse events are the source of heterogeneity. Moreover, given the differences in the number of patients included in subgroups analyzed, bias was inevitable to some extent.

In conclusion, this systematic review demonstrated that the combination treatment of ICIs is associated with a significantly higher occurrence of serious adverse events compared to ICI monotherapy. Meanwhile, our results also indicated that antiCTLA-4 agents have a higher incidence of serious adverse events compared with anti-PD-1/anti-PD-L1 agents. Pneumonitis and cardiac toxicity were the main causes of treatment-related death, but the incidence of treatmentrelated deaths was low. 


\section{DATA AVAILABILITY STATEMENT}

The original contributions presented in the study are included in the article/Supplementary Material. Further inquiries can be directed to the corresponding authors.

\section{AUTHOR CONTRIBUTIONS}

$\mathrm{CZ}, \mathrm{BL}$, and BX contributed conception/design. TO, YC, and XK contributed in collection of assembly of data. LC, YR, TS, and LY performed data analysis and interpretation. All authors contributed to the article and approved the submitted version.

\section{REFERENCES}

1. Li X, Shao C, Shi Y, Han W. Lessons Learned From the Blockade of Immune Checkpoints in Cancer Immunotherapy. J Hematol Oncol (2018) 11(1):31. doi: 10.1186/s13045-018-0578-4

2. Seidel JA, Otsuka A, Kabashima K. Anti-PD-1 and Anti-CTLA-4 Therapies in Cancer: Mechanisms of Action, Efficacy, and Limitations. Front Oncol (2018) 8:86. doi: 10.3389/fonc.2018.00086

3. Gu L, Khadaroo PA, Su H, Kong L, Chen L, Wang X, et al. The Safety and Tolerability of Combined Immune Checkpoint Inhibitors (anti-PD-1/PDL1 Plus anti-CTLA-4): A Systematic Review and Meta-Analysis. BMC Cancer (2019) 19(1):559. doi: 10.1186/s12885-019-5785-Z

4. Park R, Lopes L, Cristancho CR, Riano IM, Saeed A. Treatment-Related Adverse Events of Combination Immune Checkpoint Inhibitors: Systematic Review and Meta-Analysis. Front Oncol (2020) 10:258. doi: 10.3389/ fonc. 2020.00258

5. Santini FC, Rizvi H, Plodkowski AJ, Ni A, Lacouture ME, Gambarin-Gelwan M, et al. Safety and Efficacy of Re-treating With Immunotherapy After Immune-Related Adverse Events in Patients With NSCLC. Cancer Immunol Res (2018) 6(9):1093-9. doi: 10.1158/2326-6066.CIR-17-0755

6. Adams S, Loi S, Toppmeyer D, Cescon DW, De Laurentiis M, Nanda R, et al. Pembrolizumab Monotherapy for Previously Untreated, PD-L1-positive, Metastatic Triple-Negative Breast Cancer: Cohort B of the Phase II KEYNOTE-086 Study. Ann Oncol (2019) 30(3):405-11. doi: 10.1093/ annonc/mdy518

7. Carlino MS, Long GV, Schadendorf D, Robert C, Ribas A, Richtig E, et al. Outcomes by Line of Therapy and Programmed Death Ligand 1 Expression in Patients With Advanced Melanoma Treated With Pembrolizumab or Ipilimumab in KEYNOTE-006: A Randomised Clinical Trial. Eur J Cancer (2018) 101:236-43. doi: 10.1016/j.ejca.2018.06.034

8. D'Angelo SP, Mahoney MR, Van Tine BA, Atkins J, Milhem MM, Jahagirdar BN, et al. Nivolumab With or Without Ipilimumab Treatment for Metastatic Sarcoma (Alliance A091401): Two Open-Label, NonComparative, Randomised, Phase 2 Trials. Lancet Oncol (2018) 19 (3):416-26. doi: 10.1016/s1470-2045(18)30006-8

9. Eggermont AMM, Blank CU, Mandala M, Long GV, Atkinson V, Dalle S, et al. Adjuvant Pembrolizumab Versus Placebo in Resected Stage III Melanoma. N Engl J Med (2018) 378(19):1789-801. doi: 10.1056/ NEJMoa 1802357

10. Ferris RL, Blumenschein G Jr, Fayette J, Guigay J, Colevas AD, Licitra L, et al. Nivolumab vs Investigator's Choice in Recurrent or Metastatic Squamous Cell Carcinoma of the Head and Neck: 2-Year Long-Term Survival Update of CheckMate 141 With Analyses by Tumor PD-L1 Expression. Oral Oncol (2018) 81:45-51. doi: 10.1016/j.oraloncology.2018.04.008

11. Fuchs CS, Doi T, Jang RW, Muro K, Satoh T, Machado M, et al. Safety and Efficacy of Pembrolizumab Monotherapy in Patients With Previously Treated Advanced Gastric and Gastroesophageal Junction Cancer: Phase 2 Clinical KEYNOTE-059 Trial. JAMA Oncol (2018) 4(5):e180013. doi: 10.1001/jamaoncol.2018.0013

12. Hellmann MD, Ciuleanu TE, Pluzanski A, Lee JS, Otterson GA, AudigierValette C, et al. Nivolumab Plus Ipilimumab in Lung Cancer With a High

\section{FUNDING}

This study was supported by a grant from the National Natural Science Foundation of China (Nos. 81873919).

\section{SUPPLEMENTARY MATERIAL}

The Supplementary Material for this article can be found online at: https://www.frontiersin.org/articles/10.3389/fonc.2021. 621639/full\#supplementary-material

Tumor Mutational Burden. N Engl J Med (2018) 378(22):2093-104 doi: 10.1056/NEJMoa1801946

13. Johnson ML, Braiteh F, Grilley-Olson JE, Chou J, Davda J, Forgie A, et al. Assessment of Subcutaneous vs Intravenous Administration of Anti-PD-1 Antibody PF-06801591 in Patients With Advanced Solid Tumors. JAMA Oncol (2019) 5(7):999. doi: 10.1001/jamaoncol.2019.0836

14. Keilholz U, Mehnert JM, Bauer S, Bourgeois H, Patel MR, Gravenor D, et al. Avelumab in Patients With Previously Treated Metastatic Melanoma: Phase 1b Results From the JAVELIN Solid Tumor Trial. J Immunother Cancer (2019) 7(1):12. doi: 10.1186/s40425-018-0459-y

15. McDermott DF, Huseni MA, Atkins MB, Motzer RJ, Rini BI, Escudier B et al. Clinical Activity and Molecular Correlates of Response to Atezolizumab Alone or in Combination With Bevacizumab Versus Sunitinib in Renal Cell Carcinoma. Nat Med (2018) 24(6):749-57. doi: 10.1038/s41591-018-0053-3

16. Mehnert JM, Varga A, Brose MS, Aggarwal RR, Lin CC, Prawira A, et al Safety and Antitumor Activity of the anti-PD-1 Antibody Pembrolizumab in Patients With Advanced, PD-L1-positive Papillary or Follicular Thyroid Cancer. BMC Cancer (2019) 19(1):196. doi: 10.1186/s12885019-5380-3

17. Mehra R, Seiwert TY, Gupta S, Weiss J, Gluck I, Eder JP, et al. Efficacy and Safety of Pembrolizumab in Recurrent/Metastatic Head and Neck Squamous Cell Carcinoma: Pooled Analyses After Long-Term Follow-Up in KEYNOTE-012. Br J Cancer (2018) 119(2):153-9. doi: 10.1038/s41416018-0131-9

18. Migden MR, Rischin D, Schmults CD, Guminski A, Hauschild A, Lewis KD, et al. PD-1 Blockade With Cemiplimab in Advanced Cutaneous SquamousCell Carcinoma. N Engl J Med (2018) 379(4):341-51. doi: 10.1056/ NEJMoa1805131

19. Nishio M, Takahashi T, Yoshioka H, Nakagawa K, Fukuhara T, Yamada K et al. KEYNOTE-025: Phase $1 \mathrm{~b}$ Study of Pembrolizumab in Japanese Patients With Previously Treated Programmed Death Ligand 1-Positive Advanced non-Small-Cell Lung Cancer. Cancer Sci (2019) 110(3):1012-20. doi: $10.1111 /$ cas. 13932

20. Nishio S, Matsumoto K, Takehara K, Kawamura N, Hasegawa K, Takeshima $\mathrm{N}$, et al. Pembrolizumab Monotherapy in Japanese Patients With Advanced Ovarian Cancer: Subgroup Analysis From the KEYNOTE-100. Cancer Sci (2020) 111(4):1324-32. doi: 10.1111/cas.14340

21. Nishiyama H, Yamamoto Y, Sassa N, Nishimura K, Fujimoto K, Fukasawa S et al. Pembrolizumab Versus Chemotherapy in Recurrent, Advanced Urothelial Cancer in Japanese Patients: A Subgroup Analysis of the Phase 3 KEYNOTE-045 Trial. Int J Clin Oncol (2020) 25(1):165-74. doi: 10.1007/ s10147-019-01545-4

22. Omuro A, Vlahovic G, Lim M, Sahebjam S, Baehring J, Cloughesy T, et al. Nivolumab With or Without Ipilimumab in Patients With Recurrent Glioblastoma: Results From Exploratory Phase I Cohorts of CheckMate 143. Neuro Oncol (2018) 20(5):674-86. doi: 10.1093/neuonc/nox208

23. Petrylak DP, Powles T, Bellmunt J, Braiteh F, Loriot Y, Morales-Barrera R, et al. Atezolizumab (MPDL3280A) Monotherapy for Patients With Metastatic Urothelial Cancer: Long-Term Outcomes From a Phase 1 Study. JAMA Oncol (2018) 4(4):537-44. doi: 10.1001/jamaoncol.2017.5440 
24. Ready N, Farago AF, de Braud F, Atmaca A, Hellmann MD, Schneider JG, et al. Third-Line Nivolumab Monotherapy in Recurrent SCLC: CheckMate 032. J Thorac Oncol (2019) 14(2):237-44. doi: 10.1016/j.jtho.2018.10.003

25. Siu LL, Even C, Mesia R, Remenar E, Daste A, Delord JP, et al. Safety and Efficacy of Durvalumab With or Without Tremelimumab in Patients With PD-L1-Low/Negative Recurrent or Metastatic HNSCC: The Phase 2 CONDOR Randomized Clinical Trial. JAMA Oncol (2019) 5(2):195-203. doi: 10.1001/jamaoncol.2018.4628

26. Tamura K, Hasegawa K, Katsumata N, Matsumoto K, Mukai H, Takahashi S, et al. Efficacy and Safety of Nivolumab in Japanese Patients With Uterine Cervical Cancer, Uterine Corpus Cancer, or Soft Tissue Sarcoma: Multicenter, Open-Label Phase 2 Trial. Cancer Sci (2019) 110(9):2894904. doi: $10.1111 /$ cas. 14148

27. Tarhini AA, Lee SJ, Li X, Rao UNM, Nagarajan A, Albertini MR, et al. E3611-a Randomized Phase II Study of Ipilimumab At 3 or $10 \mathrm{mg} / \mathrm{kg}$ Alone or in Combination With High-Dose Interferon-alpha2b in Advanced Melanoma. Clin Cancer Res (2019) 25(2):524-32. doi: 10.1158/10780432.CCR-18-2258

28. Tobin RP, Jordan KR, Robinson WA, Davis D, Borges VF, Gonzalez R, et al. Targeting Myeloid-Derived Suppressor Cells Using All-Trans Retinoic Acid in Melanoma Patients Treated With Ipilimumab. Int Immunopharmacol (2018) 63:282-91. doi: 10.1016/j.intimp.2018.08.007

29. Yamazaki N, Kiyohara Y, Uhara H, Fukushima S, Uchi H, Shibagaki N, et al. Phase II Study of Ipilimumab Monotherapy in Japanese Patients With Advanced Melanoma. Cancer Chemother Pharmacol (2015) 76(5):9971004. doi: 10.1007/s00280-015-2873-x

30. Zimmer L, Eigentler TK, Kiecker F, Simon J, Utikal J, Mohr P, et al. OpenLabel, Multicenter, Single-Arm Phase II DeCOG-study of Ipilimumab in Pretreated Patients With Different Subtypes of Metastatic Melanoma. J Trans Med (2015) 13:351. doi: 10.1186/s12967-015-0716-5

31. Zimmer L, Vaubel J, Mohr P, Hauschild A, Utikal J, Simon J, et al. Phase II DeCOG-study of Ipilimumab in Pretreated and Treatment-Naive Patients With Metastatic Uveal Melanoma. PloS One (2015) 10(3):e0118564. doi: 10.1371/journal.pone. 0118564

32. Adams S, Schmid P, Rugo HS, Winer EP, Loirat D, Awada A, et al. Pembrolizumab Monotherapy for Previously Treated Metastatic TripleNegative Breast Cancer: Cohort A of the Phase II KEYNOTE-086 Study. Ann Oncol (2019) 30(3):397-404. doi: 10.1093/annonc/mdy517

33. Adra N, Einhorn LH, Althouse SK, Ammakkanavar NR, Musapatika D, Albany C, et al. Phase II Trial of Pembrolizumab in Patients With Platinum Refractory Germ-Cell Tumors: A Hoosier Cancer Research Network Study GU14-206. Ann Oncol (2018) 29(1):209-14. doi: 10.1093/ annonc/mdx680

34. Ansell SM, Lesokhin AM, Borrello I, Halwani A, Scott EC, Gutierrez M, et al. PD-1 Blockade With Nivolumab in Relapsed or Refractory Hodgkin's Lymphoma. N Engl J Med (2015) 372(4):311-9. doi: 10.1056/ NEJMoa1411087

35. Antonia SJ, Villegas A, Daniel D, Vicente D, Murakami S, Hui R, et al. Durvalumab After Chemoradiotherapy in Stage Iii Non-Small-Cell Lung Cancer. N Engl J Med (2017) 377(20):1919-29. doi: 10.1056/ NEJMoa1709937

36. Armand P, Shipp MA, Ribrag V, Michot JM, Zinzani PL, Kuruvilla J, et al. Programmed Death-1 Blockade With Pembrolizumab in Patients With Classical Hodgkin Lymphoma After Brentuximab Vedotin Failure. J Clin Oncol (2016) 34(31):3733-9. doi: 10.1200/JCO.2016.67.3467

37. Ascierto PA, Long GV, Robert C, Brady B, Dutriaux C, Di Giacomo AM, et al. Survival Outcomes in Patients With Previously Untreated BRAF WildType Advanced Melanoma Treated With Nivolumab Therapy: Three-Year Follow-Up of a Randomized Phase 3 Trial. JAMA Oncol (2019) 5(2):187-94. doi: 10.1001/jamaoncol.2018.4514

38. Balar AV, Galsky MD, Rosenberg JE, Powles T, Petrylak DP, Bellmunt J, et al. Atezolizumab as First-Line Treatment in Cisplatin-Ineligible Patients With Locally Advanced and Metastatic Urothelial Carcinoma: A SingleArm, Multicentre, Phase 2 Trial. Lancet (2017) 389(10064):67-76. doi: 10.1016/s0140-6736(16)32455-2

39. Bang YJ, Cho JY, Kim YH, Kim JW, Di Bartolomeo M, Ajani JA, et al. Efficacy of Sequential Ipilimumab Monotherapy Versus Best Supportive Care for Unresectable Locally Advanced/Metastatic Gastric or
Gastroesophageal Junction Cancer. Clin Cancer Res (2017) 23(19):5671-8. doi: 10.1158/1078-0432.CCR-17-0025

40. Bang YJ, Kang YK, Catenacci DV, Muro K, Fuchs CS, Geva R, et al. Pembrolizumab Alone or in Combination With Chemotherapy as FirstLine Therapy for Patients With Advanced Gastric or Gastroesophageal Junction Adenocarcinoma: Results From the Phase II Nonrandomized KEYNOTE-059 Study. Gastric Cancer (2019) 22(4):828-37. doi: 10.1007/ s10120-018-00909-5

41. Bauml J, Seiwert TY, Pfister DG, Worden F, Liu SV, Gilbert J, et al. Pembrolizumab for Platinum- and Cetuximab-Refractory Head and Neck Cancer: Results From a Single-Arm, Phase II Study. J Clin Oncol (2017) 35 (14):1542-9. doi: 10.1200/JCO.2016.70.1524

42. Bellmunt J, de Wit R, Vaughn DJ, Fradet Y, Lee JL, Fong L, et al. Pembrolizumab as Second-Line Therapy for Advanced Urothelial Carcinoma. N Engl J Med (2017) 376(11):1015-26. doi: 10.1056/ NEJMoal613683

43. Ben-Ami E, Barysauskas CM, Solomon S, Tahlil K, Malley R, Hohos M, et al. Immunotherapy With Single Agent Nivolumab for Advanced Leiomyosarcoma of the Uterus: Results of a Phase 2 Study. Cancer (2017) 123(17):3285-90. doi: 10.1002/cncr.30738

44. Borghaei H, Paz-Ares L, Horn L, Spigel DR, Steins M, Ready NE, et al. Nivolumab Versus Docetaxel in Advanced Nonsquamous Non-Small-Cell Lung Cancer. N Engl J Med (2015) 373(17):1627-39. doi: 10.1056/ NEJMoa1507643

45. Brahmer J, Reckamp KL, Baas P, Crino L, Eberhardt WE, Poddubskaya E, et al. Nivolumab Versus Docetaxel in Advanced Squamous-Cell Non-SmallCell Lung Cancer. N Engl J Med (2015) 373(2):123-35. doi: 10.1056/ NEJMoa1504627

46. Colevas AD, Bahleda R, Braiteh F, Balmanoukian A, Brana I, Chau NG, et al. Safety and Clinical Activity of Atezolizumab in Head and Neck Cancer: Results From a Phase I Trial. Ann Oncol (2018) 29(11):2247-53. doi: 10.1093/annonc/mdy411

47. Ding W, LaPlant BR, Call TG, Parikh SA, Leis JF, He R, et al. Pembrolizumab in Patients With CLL and Richter Transformation or With Relapsed CLL. Blood (2017) 129(26):3419-27. doi: 10.1182/blood2017-02-765685

48. Eggermont AM, Chiarion-Sileni V, Grob JJ, Dummer R, Wolchok JD, Schmidt $\mathrm{H}$, et al. Prolonged Survival in Stage Iii Melanoma With Ipilimumab Adjuvant Therapy. N Engl J Med (2016) 375(19):1845-55. doi: 10.1056/NEJMoa1611299

49. Emens LA, Cruz C, Eder JP, Braiteh F, Chung C, Tolaney SM, et al. LongTerm Clinical Outcomes and Biomarker Analyses of Atezolizumab Therapy for Patients With Metastatic Triple-Negative Breast Cancer: A Phase 1 Study. JAMA Oncol (2019) 5(1):74-82. doi: 10.1001/jamaoncol.2018.4224

50. Ferris RL, Blumenschein G Jr, Fayette J, Guigay J, Colevas AD, Licitra L, et al. Nivolumab for Recurrent Squamous-Cell Carcinoma of the Head and Neck. N Engl J Med (2016) 375(19):1856-67. doi: 10.1056/NEJMoa1602252

51. Fujiwara $Y$, Iguchi $H$, Yamamoto $N$, Hayama M, Nii M, Ueda $S$, et al. Tolerability and Efficacy of Durvalumab in Japanese Patients With Advanced Solid Tumors. Cancer Sci (2019) 110(5):1715-23. doi: 10.1111/ cas. 14003

52. Garon EB, Rizvi NA, Hui R, Leighl N, Balmanoukian AS, Eder JP, et al. Pembrolizumab for the Treatment of Non-Small-Cell Lung Cancer. N Engl J Med (2015) 372(21):2018-28. doi: 10.1056/NEJMoa1501824

53. Gettinger S, Rizvi NA, Chow LQ, Borghaei H, Brahmer J, Ready N, et al. Nivolumab Monotherapy for First-Line Treatment of Advanced non-SmallCell Lung Cancer. J Clin Oncol (2016) 34(25):2980-7. doi: 10.1200/ JCO.2016.66.9929

54. Gettinger SN, Horn L, Gandhi L, Spigel DR, Antonia SJ, Rizvi NA, et al. Overall Survival and Long-Term Safety of Nivolumab (Anti-Programmed Death 1 Antibody, Bms-936558, ONO-4538) in Patients With Previously Treated Advanced non-Small-Cell Lung Cancer. J Clin Oncol (2015) 33 (18):2004-12. doi: 10.1200/JCO.2014.58.3708

55. Hida T, Kaji R, Satouchi M, Ikeda N, Horiike A, Nokihara H, et al. Atezolizumab in Japanese Patients With Previously Treated Advanced Non-Small-Cell Lung Cancer: A Subgroup Analysis of the Phase 3 OAK Study. Clin Lung Cancer (2018) 19(4):e405-e15. doi: 10.1016/ j.cllc.2018.01.004 
56. Hida T, Nishio M, Nogami N, Ohe Y, Nokihara H, Sakai H, et al. Efficacy and Safety of Nivolumab in Japanese Patients With Advanced or Recurrent Squamous non-Small Cell Lung Cancer. Cancer Sci (2017) 108(5):1000-6. doi: $10.1111 /$ cas. 13225

57. Hodi FS, Chesney J, Pavlick AC, Robert C, Grossmann KF, McDermott DF, et al. Combined Nivolumab and Ipilimumab Versus Ipilimumab Alone in Patients With Advanced Melanoma: 2-Year Overall Survival Outcomes in a Multicentre, Randomised, Controlled, Phase 2 Trial. Lancet Oncol (2016) 17 (11):1558-68. doi: 10.1016/s1470-2045(16)30366-7

58. Hui R, Garon EB, Goldman JW, Leighl NB, Hellmann MD, Patnaik A, et al. Pembrolizumab as First-Line Therapy for Patients With PD-L1-Positive Advanced non-Small Cell Lung Cancer: A Phase 1 Trial. Ann Oncol (2017) 28(4):874-81. doi: 10.1093/annonc/mdx008

59. Kato K, Satoh T, Muro K, Yoshikawa T, Tamura T, Hamamoto Y, et al. A Subanalysis of Japanese Patients in a Randomized, Double-Blind, PlaceboControlled, Phase 3 Trial of Nivolumab for Patients With Advanced Gastric or Gastro-Esophageal Junction Cancer Refractory to, or Intolerant of, At Least Two Previous Chemotherapy Regimens (ONO-4538-12, Attraction-2). Gastric Cancer (2019) 22(2):344-54. doi: 10.1007/s10120-018-0899-6

60. Larkin J, Chiarion-Sileni V, Gonzalez R, Grob JJ, Cowey CL, Lao CD, et al. Combined Nivolumab and Ipilimumab or Monotherapy in Untreated Melanoma. N Engl J Med (2015) 373(1):23-34. doi: 10.1056/ NEJMoa1504030

61. Le DT, Uram JN, Wang H, Bartlett BR, Kemberling H, Eyring AD, et al. Pd-1 Blockade in Tumors With Mismatch-Repair Deficiency. N Engl J Med (2015) 372(26):2509-20. doi: 10.1056/NEJMoa1500596

62. Lee JS, Lee KH, Cho EK, Kim DW, Kim SW, Kim JH, et al. Nivolumab in Advanced Non-Small-Cell Lung Cancer Patients Who Failed Prior Platinum-Based Chemotherapy. Lung Cancer (2018) 122:234-42. doi: 10.1016/j.lungcan.2018.05.023

63. Lee KW, Lee DH, Kang JH, Park JO, Kim SH, Hong YS, et al. Phase I Pharmacokinetic Study of Nivolumab in Korean Patients With Advanced Solid Tumors. Oncologist (2018) 23(2):155-e17. doi: 10.1634/ theoncologist.2017-0528

64. Lesokhin AM, Ansell SM, Armand P, Scott EC, Halwani A, Gutierrez M, et al. Nivolumab in Patients With Relapsed or Refractory Hematologic Malignancy: Preliminary Results of a Phase Ib Study. J Clin Oncol (2016) 34 (23):2698-704. doi: 10.1200/JCO.2015.65.9789

65. Maruyama D, Hatake K, Kinoshita T, Fukuhara N, Choi I, Taniwaki M, et al. Multicenter Phase II Study of Nivolumab in Japanese Patients With Relapsed or Refractory Classical Hodgkin Lymphoma. Cancer Sci (2017) 108(5):1007-12. doi: 10.1111/cas.13230

66. Massard C, Gordon MS, Sharma S, Rafii S, Wainberg ZA, Luke J, et al. Safety and Efficacy of Durvalumab (MEDI4736), an Anti-Programmed Cell Death Ligand-1 Immune Checkpoint Inhibitor, in Patients With Advanced Urothelial Bladder Cancer. J Clin Oncol (2016) 34(26):3119-25. doi: 10.1200/JCO.2016.67.9761

67. McDermott DF, Drake CG, Sznol M, Choueiri TK, Powderly JD, Smith DC, et al. Survival, Durable Response, and Long-Term Safety in Patients With Previously Treated Advanced Renal Cell Carcinoma Receiving Nivolumab. J Clin Oncol (2015) 33(18):2013-20. doi: 10.1200/JCO.2014.58.1041

68. Merchant MS, Wright M, Baird K, Wexler LH, Rodriguez-Galindo C, Bernstein D, et al. Phase I Clinical Trial of Ipilimumab in Pediatric Patients With Advanced Solid Tumors. Clin Cancer Res (2016) 22 (6):1364-70. doi: 10.1158/1078-0432.CCR-15-0491

69. Morris VK, Salem ME, Nimeiri H, Iqbal S, Singh P, Ciombor K, et al. Nivolumab for Previously Treated Unresectable Metastatic Anal Cancer (NCI9673): A Multicentre, Single-Arm, Phase 2 Study. Lancet Oncol (2017) 18(4):446-53. doi: 10.1016/s1470-2045(17)30104-3

70. Motzer RJ, Escudier B, McDermott DF, George S, Hammers HJ, Srinivas S, et al. Nivolumab Versus Everolimus in Advanced Renal-Cell Carcinoma. N Engl J Med (2015) 373(19):1803-13. doi: 10.1056/NEJMoa1510665

71. Motzer RJ, Rini BI, McDermott DF, Redman BG, Kuzel TM, Harrison MR, et al. Nivolumab for Metastatic Renal Cell Carcinoma: Results of a Randomized Phase II Trial. J Clin Oncol (2015) 33(13):1430-7. doi: 10.1200/JCO.2014.59.0703

72. Nanda R, Chow LQ, Dees EC, Berger R, Gupta S, Geva R, et al. Pembrolizumab in Patients With Advanced Triple-Negative Breast
Cancer: Phase Ib KEYNOTE-012 Study. J Clin Oncol (2016) 34(21):24607. doi: 10.1200/JCO.2015.64.8931

73. Necchi A, Joseph RW, Loriot Y, Hoffman-Censits J, Perez-Gracia JL, Petrylak DP, et al. Atezolizumab in Platinum-Treated Locally Advanced or Metastatic Urothelial Carcinoma: Post-Progression Outcomes From the Phase II IMvigor210 Study. Ann Oncol (2017) 28(12):3044-50. doi: 10.1093/ annonc/mdx 518

74. Nghiem PT, Bhatia S, Lipson EJ, Kudchadkar RR, Miller NJ, Annamalai L, et al. PD-1 Blockade With Pembrolizumab in Advanced Merkel-Cell Carcinoma. N Engl J Med (2016) 374(26):2542-52. doi: 10.1056/NEJMoa1603702

75. O'Neil BH, Wallmark JM, Lorente D, Elez E, Raimbourg J, Gomez-Roca C, et al. Safety and Antitumor Activity of the anti-PD-1 Antibody Pembrolizumab in Patients With Advanced Colorectal Carcinoma. PloS One (2017) 12(12):e0189848. doi: 10.1371/journal.pone.0189848

76. Ott PA, Piha-Paul SA, Munster P, Pishvaian MJ, van Brummelen EMJ, Cohen RB, et al. Safety and Antitumor Activity of the anti-PD-1 Antibody Pembrolizumab in Patients With Recurrent Carcinoma of the Anal Canal. Ann Oncol (2017) 28(5):1036-41. doi: 10.1093/annonc/mdx029

77. Overman MJ, McDermott R, Leach JL, Lonardi S, Lenz H-J, Morse MA, et al. Nivolumab in Patients With Metastatic DNA Mismatch Repair-Deficient or Microsatellite Instability-High Colorectal Cancer (CheckMate 142): An Open-Label, Multicentre, Phase 2 Study. Lancet Oncol (2017) 18(9):118291. doi: 10.1016/s1470-2045(17)30422-9

78. Postow MA, Chesney J, Pavlick AC, Robert C, Grossmann K, McDermott D, et al. Nivolumab and Ipilimumab Versus Ipilimumab in Untreated Melanoma. N Engl J Med (2015) 372(21):2006-17. doi: 10.1056/ NEJMoa1414428

79. Powles T, O’Donnell PH, Massard C, Arkenau HT, Friedlander TW, Hoimes CJ, et al. Efficacy and Safety of Durvalumab in Locally Advanced or Metastatic Urothelial Carcinoma: Updated Results From a Phase 1/2 Open-label Study. JAMA Oncol (2017) 3(9):e172411. doi: 10.1001/ jamaoncol.2017.2411

80. Reck M, Rodriguez-Abreu D, Robinson AG, Hui R, Csoszi T, Fulop A, et al. Pembrolizumab Versus Chemotherapy for PD-L1-Positive non-Small-Cell Lung Cancer. N Engl J Med (2016) 375(19):1823-33. doi: 10.1056/ NEJMoa1606774

81. Rittmeyer A, Barlesi F, Waterkamp D, Park K, Ciardiello F, von Pawel J, et al. Atezolizumab Versus Docetaxel in Patients With Previously Treated NonSmall-Cell Lung Cancer (OAK): A Phase 3, Open-Label, Multicentre Randomised Controlled Trial. Lancet (2017) 389(10066):255-65. doi: 10.1016/s0140-6736(16)32517-x

82. Robert C, Long GV, Brady B, Dutriaux C, Maio M, Mortier L, et al. Nivolumab in Previously Untreated Melanoma Without BRAF Mutation. N Engl J Med (2015) 372(4):320-30. doi: 10.1056/NEJMoa1412082

83. Robert C, Schachter J, Long GV, Arance A, Grob JJ, Mortier L, et al. Pembrolizumab Versus Ipilimumab in Advanced Melanoma. N Engl J Med (2015) 372(26):2521-32. doi: 10.1056/NEJMoa1503093

84. Rugo HS, Delord JP, Im SA, Ott PA, Piha-Paul SA, Bedard PL, et al. Safety and Antitumor Activity of Pembrolizumab in Patients With Estrogen Receptor-Positive/Human Epidermal Growth Factor Receptor 2-Negative Advanced Breast Cancer. Clin Cancer Res (2018) 24(12):2804-11. doi: 10.1158/1078-0432.CCR-17-3452

85. Shah MA, Kojima T, Hochhauser D, Enzinger P, Raimbourg J, Hollebecque A, et al. Efficacy and Safety of Pembrolizumab for Heavily Pretreated Patients With Advanced, Metastatic Adenocarcinoma or Squamous Cell Carcinoma of the Esophagus: The Phase 2 KEYNOTE-180 Study. JAMA Oncol (2019) 5(4):546-50. doi: 10.1001/jamaoncol.2018.5441

86. Sharma P, Callahan MK, Bono P, Kim J, Spiliopoulou P, Calvo E, et al. Nivolumab Monotherapy in Recurrent Metastatic Urothelial Carcinoma (CheckMate 032): A Multicentre, Open-Label, Two-Stage, Multi-Arm, Phase 1/2 Trial. Lancet Oncol (2016) 17(11):1590-8. doi: 10.1016/s1470-2045(16) 30496-x

87. Shimizu T, Seto T, Hirai F, Takenoyama M, Nosaki K, Tsurutani J, et al. Phase 1 Study of Pembrolizumab (MK-3475; anti-PD-1 Monoclonal Antibody) in Japanese Patients With Advanced Solid Tumors. Invest New Drugs (2016) 34(3):347-54. doi: 10.1007/s10637-016-0347-6

88. Spigel DR, Chaft JE, Gettinger S, Chao BH, Dirix L, Schmid P, et al. FIR: Efficacy, Safety, and Biomarker Analysis of a Phase Ii Open-Label Study of 
Atezolizumab in PD-L1-Selected Patients With Nsclc. J Thorac Oncol (2018) 13(11):1733-42. doi: 10.1016/j.jtho.2018.05.004

89. Tahara M, Muro K, Hasegawa Y, Chung HC, Lin CC, Keam B, et al. Pembrolizumab in Asia-Pacific Patients With Advanced Head and Neck Squamous Cell Carcinoma: Analyses From KEYNOTE-012. Cancer Sci (2018) 109(3):771-6. doi: 10.1111/cas.13480

90. Tomita Y, Fukasawa S, Shinohara N, Kitamura H, Oya M, Eto M, et al. Nivolumab Versus Everolimus in Advanced Renal Cell Carcinoma: Japanese Subgroup Analysis From the CheckMate 025 Study. Jpn J Clin Oncol (2017) 47(7):639-46. doi: 10.1093/jjco/hyx049

91. Weber J, Mandala M, Del Vecchio M, Gogas HJ, Arance AM, Cowey CL, et al. Adjuvant Nivolumab Versus Ipilimumab in Resected Stage III or IV Melanoma. N Engl J Med (2017) 377(19):1824-35. doi: 10.1056/ NEJMoa1709030

92. Wolchok JD, Chiarion-Sileni V, Gonzalez R, Rutkowski P, Grob JJ, Cowey CL, et al. Overall Survival With Combined Nivolumab and Ipilimumab in Advanced Melanoma. N Engl J Med (2017) 377(14):1345-56. doi: 10.1056/ NEJMoa1709684

93. Yamamoto N, Nokihara H, Yamada Y, Shibata T, Tamura Y, Seki Y, et al. Phase I Study of Nivolumab, an anti-PD-1 Antibody, in Patients With Malignant Solid Tumors. Invest New Drugs (2017) 35(2):207-16. doi: 10.1007/s10637-016-0411-2

94. Yamazaki N, Kiyohara Y, Uhara H, Uehara J, Fujimoto M, Takenouchi T, et al. Efficacy and Safety of Nivolumab in Japanese Patients With Previously Untreated Advanced Melanoma: A Phase II Study. Cancer Sci (2017) 108 (6):1223-30. doi: 10.1111/cas.13241

95. Yamazaki N, Takenouchi T, Fujimoto M, Ihn H, Uchi H, Inozume T, et al. Phase 1b Study of Pembrolizumab (MK-3475; anti-PD-1 Monoclonal Antibody) in Japanese Patients With Advanced Melanoma (KEYNOTE041). Cancer Chemother Pharmacol (2017) 79(4):651-60. doi: 10.1007/ s00280-016-3237-x

96. Younes A, Santoro A, Shipp M, Zinzani PL, Timmerman JM, Ansell S, et al. Nivolumab for Classical Hodgkin's Lymphoma After Failure of Both Autologous Stem-Cell Transplantation and Brentuximab Vedotin: A Multicentre, Multicohort, Single-Arm Phase 2 Trial. Lancet Oncol (2016) 17(9):1283-94. doi: 10.1016/s1470-2045(16)30167-x

97. Zinzani PL, Ribrag V, Moskowitz CH, Michot JM, Kuruvilla J, Balakumaran A, et al. Safety and Tolerability of Pembrolizumab in Patients With Relapsed/Refractory Primary Mediastinal Large B-cell Lymphoma. Blood (2017) 130(3):267-70. doi: 10.1182/blood-2016-12-758383

98. Tomita Y, Kondo T, Kimura G, Inoue T, Wakumoto Y, Yao M, et al. Nivolumab Plus Ipilimumab Versus Sunitinib in Previously Untreated Advanced Renal-Cell Carcinoma: Analysis of Japanese Patients in CheckMate 214 With Extended Follow-Up. Jpn J Clin Oncol (2020) 50 (1):12-9. doi: 10.1093/jjco/hyz132

99. Atkins MB, Hodi FS, Thompson JA, McDermott DF, Hwu WJ, Lawrence DP, et al. Pembrolizumab Plus Pegylated Interferon alfa- $2 \mathrm{~b}$ or Ipilimumab for Advanced Melanoma or Renal Cell Carcinoma: Dose-Finding Results From the Phase Ib KEYNOTE-029 Study. Clin Cancer Res (2018) 24 (8):1805-15. doi: 10.1158/1078-0432.CCR-17-3436

100. Hellmann MD, Rizvi NA, Goldman JW, Gettinger SN, Borghaei H, Brahmer JR, et al. Nivolumab Plus Ipilimumab as First-Line Treatment for Advanced Non-Small-Cell Lung Cancer (CheckMate 012): Results of an Open-Label, Phase 1, Multicohort Study. Lancet Oncol (2017) 18(1):31-41. doi: 10.1016/ s1470-2045(16)30624-6

101. Antonia S, Goldberg SB, Balmanoukian A, Chaft JE, Sanborn RE, Gupta A, et al. Safety and Antitumour Activity of Durvalumab Plus Tremelimumab in Non-Small Cell Lung Cancer: A Multicentre, Phase 1b Study. Lancet Oncol (2016) 17(3):299-308. doi: 10.1016/s1470-2045(15)00544-6

102. Weber JS, Gibney G, Sullivan RJ, Sosman JA, Slingluff CL, Lawrence DP, et al. Sequential Administration of Nivolumab and Ipilimumab With a Planned Switch in Patients With Advanced Melanoma (CheckMate 064): An Open-Label, Randomised, Phase 2 Trial. Lancet Oncol (2016) 17(7):943-55. doi: 10.1016/s1470-2045(16)30126-7

103. Motzer RJ, Tannir NM, McDermott DF, Aren Frontera O, Melichar B, Choueiri TK, et al. Nivolumab Plus Ipilimumab Versus Sunitinib in Advanced Renal-Cell Carcinoma. N Engl J Med (2018) 378(14):1277-90. doi: 10.1056/NEJMoa1712126
104. Tawbi HA, Forsyth PA, Algazi A, Hamid O, Hodi FS, Moschos SJ, et al. Combined Nivolumab and Ipilimumab in Melanoma Metastatic to the Brain. N Engl J Med (2018) 379(8):722-30. doi: 10.1056/NEJMoa1805453

105. Namikawa K, Kiyohara Y, Takenouchi T, Uhara H, Uchi H, Yoshikawa S, et al. Efficacy and Safety of Nivolumab in Combination With Ipilimumab in Japanese Patients With Advanced Melanoma: An Open-Label, Single-Arm, Multicentre Phase II Study. Eur J Cancer (2018) 105:114-26. doi: 10.1016/ j.ejca.2018.09.025

106. Herrera AF, Goy A, Mehta A, Ramchandren R, Pagel JM, Svoboda J, et al. Safety and Activity of Ibrutinib in Combination With Durvalumab in Patients With Relapsed or Refractory Follicular Lymphoma or Diffuse Large B-cell Lymphoma. Am J Hematol (2020) 95(1):18-27. doi: 10.1002/ ajh. 25659

107. Paz-Ares L, Luft A, Vicente D, Tafreshi A, Gumus M, Mazieres J, et al. Pembrolizumab Plus Chemotherapy for Squamous non-Small-Cell Lung Cancer. N Engl J Med (2018) 379(21):2040-51. doi: 10.1056/ NEJMoa1810865

108. Gandhi L, Rodriguez-Abreu D, Gadgeel S, Esteban E, Felip E, De Angelis F, et al. Pembrolizumab Plus Chemotherapy in Metastatic Non-Small-Cell Lung Cancer. N Engl J Med (2018) 378(22):2078-92. doi: 10.1056/ NEJMoa 1801005

109. Amin A, Plimack ER, Ernstoff MS, Lewis LD, Bauer TM, McDermott DF, et al. Safety and Efficacy of Nivolumab in Combination With Sunitinib or Pazopanib in Advanced or Metastatic Renal Cell Carcinoma: The CheckMate 016 Study. J Immunother Cancer (2018) 6(1):109. doi: 10.1186/ s40425-018-0420-0

110. Atkins MB, Plimack ER, Puzanov I, Fishman MN, McDermott DF, Cho DC, et al. Axitinib in Combination With Pembrolizumab in Patients With Advanced Renal Cell Cancer: A non-Randomised, Open-Label, DoseFinding, and Dose-Expansion Phase 1b Trial. Lancet Oncol (2018) 19 (3):405-15. doi: 10.1016/s1470-2045(18)30081-0

111. Gettinger S, Hellmann MD, Chow LQM, Borghaei H, Antonia S, Brahmer JR, et al. Nivolumab Plus Erlotinib in Patients With EGFR-Mutant Advanced Nsclc. J Thorac Oncol (2018) 13(9):1363-72. doi: 10.1016/j.jtho.2018.05.015

112. Wrangle JM, Velcheti V, Patel MR, Garrett-Mayer E, Hill EG, Ravenel JG, et al. ALT-803, an IL-15 Superagonist, in Combination With Nivolumab in Patients With Metastatic non-Small Cell Lung Cancer: A Non-Randomised, Open-Label, Phase 1b Trial. Lancet Oncol (2018) 19(5):694-704. doi: 10.1016/s1470-2045(18)30148-7

113. Massarelli E, William W, Johnson F, Kies M, Ferrarotto R, Guo M, et al. Combining Immune Checkpoint Blockade and Tumor-Specific Vaccine for Patients With Incurable Human Papillomavirus 16-Related Cancer: A Phase 2 Clinical Trial. JAMA Oncol (2019) 5(1):67-73. doi: 10.1001/ jamaoncol.2018.4051

114. Arkenau HT, Martin-Liberal J, Calvo E, Penel N, Krebs MG, Herbst RS, et al. Ramucirumab Plus Pembrolizumab in Patients With Previously Treated Advanced or Metastatic Biliary Tract Cancer: Nonrandomized, Open-Label, Phase I Trial (JVDF). Oncologist (2018) 23(12):1407-e136. doi: 10.1634/ theoncologist.2018-0044

115. Parikh M, Pan CX, Beckett LA, Li Y, Robles DA, Aujla PK, et al. Pembrolizumab Combined With Either Docetaxel or Gemcitabine in Patients With Advanced or Metastatic Platinum-Refractory Urothelial Cancer: Results From a Phase I Study. Clin Genitourin Cancer (2018) 16 (6):421-8 e1. doi: 10.1016/j.clgc.2018.07.004

116. Tolcher AW, Sznol M, Hu-Lieskovan S, Papadopoulos KP, Patnaik A, Rasco DW, et al. Phase Ib Study of Utomilumab (PF-05082566), a 4-1BB/CD137 Agonist, in Combination With Pembrolizumab (MK-3475) in Patients With Advanced Solid Tumors. Clin Cancer Res (2017) 23(18):5349-57. doi: 10.1158/1078-0432.CCR-17-1243

117. Tang C, Welsh JW, de Groot P, Massarelli E, Chang JY, Hess KR, et al. Ipilimumab With Stereotactic Ablative Radiation Therapy: Phase I Results and Immunologic Correlates From Peripheral T Cells. Clin Cancer Res (2017) 23(6):1388-96. doi: 10.1158/1078-0432.CCR-16-1432

118. D'Angelo SP, Shoushtari AN, Keohan ML, Dickson MA, Gounder MM, Chi P, et al. Combined KIT and CTLA-4 Blockade in Patients With Refractory GIST and Other Advanced Sarcomas: A Phase Ib Study of Dasatinib Plus Ipilimumab. Clin Cancer Res (2017) 23(12):2972-80. doi: 10.1158/10780432.CCR-16-2349 
119. Reilley MJ, Bailey A, Subbiah V, Janku F, Naing A, Falchook G, et al. Phase I Clinical Trial of Combination Imatinib and Ipilimumab in Patients With Advanced Malignancies. J Immunother Cancer (2017) 5:35. doi: 10.1186/ s40425-017-0238-1

120. Langer CJ, Gadgeel SM, Borghaei H, Papadimitrakopoulou VA, Patnaik A, Powell SF, et al. Carboplatin and Pemetrexed With or Without Pembrolizumab for Advanced, non-Squamous non-Small-Cell Lung Cancer: A Randomised, Phase 2 Cohort of the Open-Label KEYNOTE-021 Study. Lancet Oncol (2016) 17(11):1497-508. doi: 10.1016/s1470-2045(16) 30498-3

121. Rizvi NA, Hellmann MD, Brahmer JR, Juergens RA, Borghaei H, Gettinger S, et al. Nivolumab in Combination With Platinum-Based Doublet Chemotherapy for First-Line Treatment of Advanced non-Small-Cell Lung Cancer. J Clin Oncol (2016) 34(25):2969-79. doi: 10.1200/JCO.2016.66.9861

122. Puzanov I, Milhem MM, Minor D, Hamid O, Li A, Chen L, et al. Talimogene Laherparepvec in Combination With Ipilimumab in Previously Untreated, Unresectable Stage IIIB-IV Melanoma. J Clin Oncol (2016) 34(22):2619-26. doi: 10.1200/JCO.2016.67.1529

123. Arriola E, Wheater M, Galea I, Cross N, Maishman T, Hamid D, et al. Outcome and Biomarker Analysis From a Multicenter Phase 2 Study of Ipilimumab in Combination With Carboplatin and Etoposide as First-Line Therapy for Extensive-Stage SCLC. J Thorac Oncol (2016) 11(9):1511-21. doi: $10.1016 /$ j.jtho.2016.05.028

124. Yamazaki N, Uhara H, Fukushima S, Uchi H, Shibagaki N, Kiyohara Y, et al. Phase II Study of the Immune-Checkpoint Inhibitor Ipilimumab Plus Dacarbazine in Japanese Patients With Previously Untreated, Unresectable or Metastatic Melanoma. Cancer Chemother Pharmacol (2015) 76(5):96975. doi: 10.1007/s00280-015-2870-0

125. Gibney GT, Kudchadkar RR, DeConti RC, Thebeau MS, Czupryn MP, Tetteh L, et al. Safety, Correlative Markers, and Clinical Results of Adjuvant Nivolumab in Combination With Vaccine in Resected High-Risk Metastatic Melanoma. Clin Cancer Res (2015) 21(4):712-20. doi: 10.1158/ 1078-0432.CCR-14-2468

126. Boku N, Ryu MH, Kato K, Chung HC, Minashi K, Lee KW, et al. Safety and Efficacy of Nivolumab in Combination With S-1/capecitabine Plus Oxaliplatin in Patients With Previously Untreated, Unresectable, Advanced, or Recurrent Gastric/Gastroesophageal Junction Cancer: Interim Results of a Randomized, Phase II Trial (ATTRACTION-4). Ann Oncol (2019) 30(2):250-8. doi: 10.1093/annonc/mdy540

127. Adams S, Diamond JR, Hamilton E, Pohlmann PR, Tolaney SM, Chang CW, et al. Atezolizumab Plus nab-Paclitaxel in the Treatment of Metastatic Triple-Negative Breast Cancer With 2-Year Survival Follow-Up: A Phase 1b Clinical Trial. JAMA Oncol (2019) 5(3):334-42. doi: 10.1001/ jamaoncol.2018.5152

128. Yang JC, Gadgeel SM, Sequist LV, Wu CL, Papadimitrakopoulou VA, Su WC, et al. Pembrolizumab in Combination With Erlotinib or Gefitinib as First-Line Therapy for Advanced NSCLC With Sensitizing EGFR Mutation. J Thorac Oncol (2019) 14(3):553-9. doi: 10.1016/j.jtho.2018.11.028

129. Iwata H, Inoue K, Kaneko K, Ito Y, Tsugawa K, Hasegawa A, et al. Subgroup Analysis of Japanese Patients in a Phase 3 Study of Atezolizumab in Advanced Triple-Negative Breast Cancer (Impassion130). Jpn J Clin Oncol (2019) 49(12):1083-91. doi: 10.1093/jjco/hyz135

130. Socinski MA, Jotte RM, Cappuzzo F, Orlandi F, Stroyakovskiy D, Nogami N, et al. Atezolizumab for First-Line Treatment of Metastatic Nonsquamous Nsclc. N Engl J Med (2018) 378(24):2288-301. doi: 10.1056/NEJMoa1716948

131. Ansell SM, Minnema MC, Johnson P, Timmerman JM, Armand P, Shipp MA, et al. Nivolumab for Relapsed/Refractory Diffuse Large B-Cell Lymphoma in Patients Ineligible for or Having Failed Autologous Transplantation: A Single-Arm, Phase Ii Study. J Clin Oncol (2019) 37 (6):481-9. doi: 10.1200/jco.18.00766

132. Lebbé C, Meyer N, Mortier L, Marquez-Rodas I, Robert C, Rutkowski P, et al. Evaluation of Two Dosing Regimens for Nivolumab in Combination With Ipilimumab in Patients With Advanced Melanoma: Results From the Phase IIIb/IV CheckMate 511 Trial. J Clin Oncol (2019) 37(11):867-75. doi: $10.1200 /$ jco. 18.01998

133. Herrera AF, Moskowitz AJ, Bartlett NL, Vose JM, Ramchandren R, Feldman TA, et al. Interim Results of Brentuximab Vedotin in Combination With
Nivolumab in Patients With Relapsed or Refractory Hodgkin Lymphoma. Blood (2018) 131(11):1183-94. doi: 10.1182/blood-2017-10-811224

134. Larkin J, Minor D, D’Angelo S, Neyns B, Smylie M, Miller WH Jr, et al. Overall Survival in Patients With Advanced Melanoma Who Received Nivolumab Versus Investigator's Choice Chemotherapy in CheckMate 037: A Randomized, Controlled, Open-Label Phase Iii Trial. J Clin Oncol (2018) 36(4):383-90. doi: 10.1200/jco.2016.71.8023

135. Chow LQM, Haddad R, Gupta S, Mahipal A, Mehra R, Tahara M, et al. Antitumor Activity of Pembrolizumab in Biomarker-Unselected Patients With Recurrent and/or Metastatic Head and Neck Squamous Cell Carcinoma: Results From the Phase Ib KEYNOTE-012 Expansion Cohort. J Clin Oncol (2016) 34(32):3838-45. doi: 10.1200/jco.2016.68.1478

136. Chen R, Zinzani PL, Lee HJ, Armand P, Johnson NA, Brice P, et al. Pembrolizumab in Relapsed or Refractory Hodgkin Lymphoma: 2-Year Follow-Up of KEYNOTE-087. Blood (2019) 134(14):1144-53. doi: 10.1182/blood.2019000324

137. Janjigian YY, Bendell J, Calvo E, Kim JW, Ascierto PA, Sharma P, et al. Checkmate-032 Study: Efficacy and Safety of Nivolumab and Nivolumab Plus Ipilimumab in Patients With Metastatic Esophagogastric Cancer. J Clin Oncol (2018) 36(28):2836-44. doi: 10.1200/jco.2017.76.6212

138. Gangadhar TC, Hwu WJ, Postow MA, Hamid O, Daud A, Dronca R, et al. Efficacy and Safety of Pembrolizumab in Patients Enrolled in KEYNOTE-030 in the United States: An Expanded Access Program. J Immunother (Hagerstown Md: 1997) (2017) 40(9):334-40. doi: 10.1097/ cji.0000000000000186

139. Atkins MB, Tarhini A, Rael M, Gupte-Singh K, O'Brien E, Ritchings C, et al. Comparative Efficacy of Combination Immunotherapy and Targeted Therapy in the Treatment of BRAF-mutant Advanced Melanoma: A Matching-Adjusted Indirect Comparison. Immunotherapy (2019) 11 (7):617-29. doi: 10.2217/imt-2018-0208

140. Hellmann MD, Paz-Ares L, Bernabe Caro R, Zurawski B, Kim SW Carcereny Costa E, et al. Nivolumab Plus Ipilimumab in Advanced nonSmall-Cell Lung Cancer. N Engl J Med (2019) 381(21):2020-31. doi: 10.1056/ NEJMoa1910231

141. Hellmann MD, Callahan MK, Awad MM, Calvo E, Ascierto PA, Atmaca A, et al. Tumor Mutational Burden and Efficacy of Nivolumab Monotherapy and in Combination With Ipilimumab in Small-Cell Lung Cancer. Cancer Cell (2018) 33(5):853-61.e4. doi: 10.1016/j.ccell.2018.04.001

142. Antonia SJ, López-Martin JA, Bendell J, Ott PA, Taylor M, Eder JP, et al. Nivolumab Alone and Nivolumab Plus Ipilimumab in Recurrent Small-Cell Lung Cancer (CheckMate 032): A Multicentre, Open-Label, Phase 1/2 Trial. Lancet Oncol (2016) 17(7):883-95. doi: 10.1016/s1470-2045(16)30098-5

143. Reck M, Schenker M, Lee KH, Provencio M, Nishio M, Lesniewski-Kmak K, et al. Nivolumab Plus Ipilimumab Versus Chemotherapy as First-Line Treatment in Advanced non-Small-Cell Lung Cancer With High Tumour Mutational Burden: Patient-Reported Outcomes Results From the Randomised, Open-Label, Phase III CheckMate 227 Trial. Eur J Cancer (2019) 116:137-47. doi: 10.1016/j.ejca.2019.05.008

144. Vokes EE, Ready N, Felip E, Horn L, Burgio MA, Antonia SJ, et al. Nivolumab Versus Docetaxel in Previously Treated Advanced non-SmallCell Lung Cancer (CheckMate 017 and CheckMate 057): 3-Year Update and Outcomes in Patients With Liver Metastases. Ann Oncol (2018) 29(4):95965. doi: 10.1093/annonc/mdy041

145. Govindan R, Szczesna A, Ahn MJ, Schneider CP, Gonzalez Mella PF, Barlesi F, et al. Phase III Trial of Ipilimumab Combined With Paclitaxel and Carboplatin in Advanced Squamous Non-Small-Cell Lung Cancer. J Clin Oncol (2017) 35(30):3449-57. doi: 10.1200/jco.2016.71.7629

146. Kudo T, Hamamoto Y, Kato K, Ura T, Kojima T, Tsushima T, et al. Nivolumab Treatment for Oesophageal Squamous-Cell Carcinoma: An Open-Label, Multicentre, Phase 2 Trial. Lancet Oncol (2017) 18(5):631-9. doi: 10.1016/s1470-2045(17)30181-x

147. Postow MA, Sidlow R, Hellmann MD. Immune-Related Adverse Events Associated With Immune Checkpoint Blockade. New Engl J Med (2018) 378 (2):158-68. doi: 10.1056/NEJMra1703481

148. Byrne EH, Fisher DE. Immune and Molecular Correlates in Melanoma Treated With Immune Checkpoint Blockade. Cancer (2017) 123(S11):214353. doi: $10.1002 /$ cncr.30444 
149. Kimbara S, Fujiwara Y, Iwama S, Ohashi K, Kuchiba A, Arima H, et al. Association of Antithyroglobulin Antibodies With the Development of Thyroid Dysfunction Induced by Nivolumab. Cancer Sci (2018) 109 (11):3583-90. doi: 10.1111/cas.13800

150. Brahmer JR, Lacchetti C, Schneider BJ, Atkins MB, Brassil KJ, Caterino JM, et al. Management of Immune-Related Adverse Events in Patients Treated With Immune Checkpoint Inhibitor Therapy: American Society of Clinical Oncology Clinical Practice Guideline. J Clin Oncol (2018) 36(17):1714-68. doi: 10.1200/JCO.2017.77.6385

151. Wang DY, Salem J-E, Cohen JV, Chandra S, Menzer C, Ye F, et al. Fatal Toxic Effects Associated With Immune Checkpoint Inhibitors. JAMA Oncol (2018) 4(12):1721. doi: 10.1001/jamaoncol.2018.3923

152. Naidoo J, Page DB, Li BT, Connell LC, Schindler K, Lacouture ME, et al. Toxicities of the Anti-PD-1 and anti-PD-L1 Immune Checkpoint Antibodies. Ann Oncol (2015) 26(12):2375-91. doi: 10.1093/annonc/mdv383

153. Fife BT, Bluestone JA. Control of Peripheral T-cell Tolerance and Autoimmunity Via the CTLA-4 and PD-1 Pathways. Immunol Rev (2008) 224:166-82. doi: 10.1111/j.1600-065X.2008.00662.x

154. Vogel I, Kasran A, Cremer J, Kim YJ, Boon L, Van Gool SW, et al. Cd28/Ctla-4/ B7 Costimulatory Pathway Blockade Affects Regulatory T-cell Function in Autoimmunity. Eur J Immunol (2015) 45(6):1832-41. doi: 10.1002/eji.201445190

155. Tai X, Cowan M, Feigenbaum L, Singer A. CD28 Costimulation of Developing Thymocytes Induces Foxp3 Expression and Regulatory T Cell Differentiation Independently of Interleukin 2. Nat Immunol (2005) 6 (2):152-62. doi: 10.1038/ni1160

156. Tang Q, Boden EK, Henriksen KJ, Bour-Jordan H, Bi M, Bluestone JA. Distinct Roles of CTLA-4 and TGF-beta in CD4+CD25+ Regulatory T Cell Function. Eur J Immunol (2004) 34(11):2996-3005. doi: 10.1002/eji.200425143

157. Walker LSK. Efis Lecture: Understanding the CTLA-4 Checkpoint in the Maintenance of Immune Homeostasis. Immunol Lett (2017) 184:43-50. doi: 10.1016/j.imlet.2017.02.007

158. Francisco LM, Sage PT, Sharpe AH. The PD-1 Pathway in Tolerance and Autoimmunity. Immunol Rev (2010) 236:219-42. doi: 10.1111/j.1600-065X.2010.00923.x

159. Keir ME, Butte MJ, Freeman GJ, Sharpe AH. PD-1 and Its Ligands in Tolerance and Immunity. Annu Rev Immunol (2008) 26(1):677-704. doi: 10.1146/annurev.immunol.26.021607.090331

160. Gonzalez-Rodriguez E, Rodriguez-Abreu D, Spanish Group for Cancer I-B. Immune Checkpoint Inhibitors: Review and Management of Endocrine Adverse Events. Oncologist (2016) 21(7):804-16. doi: 10.1634/ theoncologist.2015-0509

161. Delivanis DA, Gustafson MP, Bornschlegl S, Merten MM, Kottschade L, Withers S, et al. Pembrolizumab-Induced Thyroiditis: Comprehensive Clinical Review and Insights Into Underlying Involved Mechanisms.
J Clin Endocrinol Metab (2017) 102(8):2770-80. doi: 10.1210/jc.201700448

162. Iwama S, De Remigis A, Callahan MK, Slovin SF, Wolchok JD, Caturegli P. Pituitary Expression of CTLA-4 Mediates Hypophysitis Secondary to Administration of CTLA-4 Blocking Antibody. Sci Trans Med (2014) 6 (230):230ra45-ra45. doi: 10.1126/scitranslmed.3008002

163. Nguyen LT, Ohashi PS. Clinical Blockade of PD1 and LAG3-potential Mechanisms of Action. Nat Rev Immunol (2015) 15(1):45-56. doi: $10.1038 /$ nri3790

164. Ma W, Gilligan BM, Yuan J, Li T. Current Status and Perspectives in Translational Biomarker Research for PD-1/PD-L1 Immune Checkpoint Blockade Therapy. J Hematol Oncol (2016) 9(1):47. doi: 10.1186/s13045-0160277-y

165. Qin S, Li A, Yi M, Yu S, Zhang M, Wu K. Recent Advances on AntiAngiogenesis Receptor Tyrosine Kinase Inhibitors in Cancer Therapy. J Hematol Oncol (2019) 12(1):27. doi: 10.1186/s13045-019-0718-5

166. Naidoo J, Wang X, Woo KM, Iyriboz T, Halpenny D, Cunningham J, et al. Pneumonitis in Patients Treated With Anti-Programmed Death-1/ Programmed Death Ligand 1 Therapy. J Clin Oncol (2017) 35(7):709-17. doi: 10.1200/JCO.2016.68.2005

167. Haanen J, Carbonnel F, Robert C, Kerr KM, Peters S, Larkin J, et al. Management of Toxicities From Immunotherapy: ESMO Clinical Practice Guidelines for Diagnosis, Treatment and Follow-Up. Ann Oncol (2018) 29 (Suppl 4):iv264-iv6. doi: 10.1093/annonc/mdy162

168. Delaunay M, Cadranel J, Lusque A, Meyer N, Gounant V, Moro-Sibilot D, et al. Immune-Checkpoint Inhibitors Associated With Interstitial Lung Disease in Cancer Patients. Eur Respir J (2017) 50(2). doi: 10.1183/ 13993003.00050-2017

169. Totzeck M, Schuler M, Stuschke M, Heusch G, Rassaf T. Cardio-Oncology Strategies for Management of Cancer-Therapy Related Cardiovascular Disease. Int J Cardiol (2019) 280:163-75. doi: 10.1016/j.ijcard.2019.01.038

Conflict of Interest: The authors declare that the research was conducted in the absence of any commercial or financial relationships that could be construed as a potential conflict of interest.

Copyright (C) 2021 Ouyang, Cao, Kan, Chen, Ren, Sun, Yan, Xiong, Liang and Zheng. This is an open-access article distributed under the terms of the Creative Commons Attribution License (CC BY). The use, distribution or reproduction in other forums is permitted, provided the original author(s) and the copyright owner(s) are credited and that the original publication in this journal is cited, in accordance with accepted academic practice. No use, distribution or reproduction is permitted which does not comply with these terms. 